\title{
Italian Psychiatry
}

\author{
S. S. JoHL, Lecturer in Psychiatry, University of Sheffield
}

The dramatic changes in Italian psychiatry since 1978 when the practice of Democratic Psychiatry was officially started has had a controversial response from both inside and outside Italy. In an attempt to know more about the system that made sweeping changes in Italian psychiatry, five Italian psychiatrists and psychologists were invited to Sheffield for a two-week exposition of films, paintings, photographs, lectures and meetings on the art of Democratic Psychiatry from Italy. This was the final leg of the visit to England, after London and Manchester. The events were organized in a truly varied and democratic manner by the University Department of Psychiatry, the Division of Continuing Education at Sheffield University, and the Graves Art Gallery, in co-operation with MIND, the District Health Authority, the Family and Community Services Department, and staff from hospitals in Chesterfield, Doncaster and Sheffield. The aim of the exposition was to provide an opportunity to discuss the prospects for changes in the mental health and mental handicap services in the light of the Italian experience.

The event effectively started on 3 April 1984, at the Graves Art Gallery with the Erwin Stengel Memorial Lecture by Angelo Righetti talking about 'Franco Basaglia: His Life and Impact' to a packed audience.

Professor Franco Basaglia was born in 1923 in an upper-class Venetian family. During the war he was a partisan in the anti-fascist underground movement and, as a result, spent several months in prison, during which he had his first experience of being in a total institution. He graduated from medical school in 1953 and remained in the university department of psychiatry at Padua. Ten years later he took the unusual step of becoming a director of a psychiatric hospital in Gorizia, a small provincial town in the north of Italy. The state of psychiatry at that time was, by present standards, abysmal. The mentally ill and handicapped were managed together in large asylums which had grown from 1904 when there were 32,000 inpatients to 150,000 in 1965. The mental health law of 1904 had in a sense legalized psychiatry, giving it much of the role of the judicial system rather than of the health service. It classified the mentally ill as socially dangerous, or behaving indecently. The role of the psychiatric services was to control behaviour so that society would not be disturbed by it. It was easy for a doctor to declare that a person was difficult or dangerous, in view of which, he could be detained against his will for thirty days in an observation ward where, after thirty days. if he was still 'unwell', he would be put in a chronic ward where he was likely to be doomed to stay for the rest of his life. If he was discharged he could not join the civil service and his name was included in a special police list-he was indelibly branded for the rest of his life.

Basaglia was Italy's revolutionary psychiatrist and indeed the most successful in inducing change. He gradu- ally introduced elements of the therapeutic community, allowing patients and staff to communicate freely, drawing patients out of their isolation to greater freedom. He emphasized, as did the existentialists, the importance of not treating man as an object and that the medical model of physical illness was inappropriate. In his therapeutic community the patients, nurses and doctors, all took responsibility for each other, and decision-making was by common consensus. This, then radical approach, led to dramatic changes in the institution. Violence and aggression, so common before, began to disappear. As everyday needs began to be catered for and, as more and more began to know about the life of each person, madness became more comprehensible, and the process encouraged warmth and understanding. The emphasis was on the we feeling and what we all want to do in the hospital. Many of the general meetings initially went on for days and Basaglia would stay as everyone else. Rapidly, long-stay patients started to express their views, later to chair the meetings and produce their own newspaper. In a few years the doors were literally opened, patients began to care for themselves and each other. They worked in small groups, both inside and outside the hospital, and were paid an ordinary wage. In 1968 his first book, L'Instituzione Negata-'The Rejected Institution - appeared. (This title is not so easy to translate into English, by it Basaglia wants to draw attention to the failure of the large mental hospital, but even more to repudiate a possible justification for it.) It was also the year of student workers' rebellion and the beginning of the women's movement. The Gorizia experiment itself reflected this cultural change. Basaglia's writings, for a strange reason, have still to be translated into English and they include 'The Death of a Class'. 'The Deviant Majority' and 'The Criminals of Peace'.

In 1970 Basaglia moved to Trieste where he led the creation of the community mental health centres with beds and walk-in centres that quickly replaced the psychiatric hospital. The best part of the hospital, the director's house. was converted into flats for the more independent. and others were moved to houses in the community.

In 1976. Basaglia and others formed a movement called 'Psichiatrica Democratica' which spearheaded radical changes that spread to other places like Arezzo. Perugia. Ferrar. Parma, Genoa. Turin and Bari. The system was democratic in that it involved the patients, staff and community. The spirit of democracy emphasized the freedom to choose one's ends and direct one's course in an effort to realize them at the same time observing the needs of the community, rather than the 'legitimized' dictatorship of the 'deviant' majority. It was a move to demystify a psychiatry with the idea that the professional knows best. This occurred understandably amidst great opposition from the traditional establishment. including academic institutions which found all this too threatening. In 1978. 
due to the untiring efforts of Basaglia and his group. after collecting half a million signatures pressing for a change. the Italian parliament passed the Mental Treatment Act. also known as the Law No 180. which underlined the desirability of the closure of psychiatric hospitals and that steps were to be taken to establish community mental health centres. There were to be no more than 15 beds per 200.000 of the general population. Such a radical change also ensured that no staff member would be made redundant because of the reform. It emphasized that the activities of prevention. therapy and rehabilitation were to be carried out from a non-hospital base. The change was therefore total. and it had to be if it was to work.

During their two-week stay here, our Italian visitors met social workers. mental health workers. psychiatric staff. hospital administrators. patients, voluntary organizations. the probation and after-care services. politicians, students and other interested groups. It was interesting to see so much enthusiasm from the non-psychiatric public and it clearly showed that there is perhaps a large, silent body of people concerned about mental health. It showed that many were interested but wary about the way professionals worked. Many questioned the control and power that psychiatrists had over the vulnerable and emotionally disturbed.

The Italians were critical about the lack of integration of the various services and their tendency to serve the professionals' needs rather than the patients'. Their approach centered on a well-developed crisis intervention arrangement. manned by nurses. doctors. psychologists and social workers to provide a quick and efficient service for their patients to be seen with their families in the social environment in which they live. and to attempt to resolve the problem without taking the patient away from the troubled situation. Rarely, there would be a case to remove the patient and for this they have no more than 15 beds per 200,000 of the general population. either in a general hospital or in a mental health centre. It was unusual for all the 15 beds to be used. This also forced a considerably greater involvement in human relationships by those concerned. In the case of violent patients, or if a crime was committed, it would be a problem for the law and. if concurrently there was a need for psychiatric treatment. it was accordingly provided. This emphasized the difference between illness and responsibility. It is interesting that our visitors commented that this affected the presenting symptomatology of previously violent patients.

The community health centres are open for anyone to drop in without the need for a general practitioner referral. and they are seen by whoever is available. Little emphasis is put on drug treatments. The community health centre has a fairly strict and small catchment area so that it becomes part of the small community it serves. It involves itself with the town's housing. education. welfare. planning. employment and other agencies. In this way it represents the mentally ill as well as the society they belong to. thus reducing fear and suspicion on both sides. The needs of the elderly demented population were seen as a separate issue. that is dealt with by a service of its own.

There has been considerable criticism in Italy of this system. Accepting Basaglia's ideas would mean questioning some very fundamental issues in psychiatry. It would mean paying greater emphasis to the person, his world. and the way society behaves rather than the traditional view that psychiatry is part of medicine and biochemistry as a means of solving problems that are essentially human. Such a system shifts a considerable part of the responsibility to the patient, and more so to the family who may be ill-equipped to bear the burden. On the other hand. this system provides early attention and care and encourages a greater involvement in the patients' lives and their families. Direct access to the community centres without having to go through the general practitioner means a quicker referral. Huge hospitals, with their administration and related staff. then do not need to be maintained and occupational therapy services can be reduced to a small scale. Opponents of this system claim that it has not worked out as they hoped, and that many of the old hospitals still exist, understaffed and poorly maintained. with a lack of community resources. A lack of statistics makes it difficult to assess change. and information is mainly anecdotal and varies greatly from place to place. but there is little doubt that, in principle. the movement is a more humane one. Even our enthusiastic Italian visitors maintained that it would be wrong for them to say that their system was without fault and theirs was only a necessary step to the next stage.

\section{University of Oxford, Neurosciences Course}

An intensive course in neurosciences will be held in the University Department of Human Anatomy from 16 to 20 September 1985. This annual course provides an intensive up-to-date review of the neurosciences for physicians. psychiatrists. psychologists and others interested in this field. The basic sciences component is suitable for those preparing for the MRCPsych and other examinatioins. Residential accommodation will be available. Enquiries: Director of Postgraduate Medical Education and Training. Medical School Offices. Level 3. John Radcliffe Hospital. Headington. Oxford OX3 9DU. 